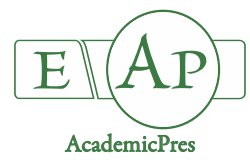

\title{
Effects of Vermicompost on Some Morphological, Physiological and Biochemical Parameters of Lettuce (Lactuca sativa var. crispa) under Drought Stress
}

\author{
Sevinç KIRAN \\ Soil Fertilizer and Water Resources Central Research Institute, Ankara 06172, Turkey; sevinckiran@tgae.gov.tr
}

\begin{abstract}
Vermicompost can play an effective and important role in plant growth and development and also in reducing harmful effects of various environmental stresses on plants. The vermicompost fertilizer application was evaluated for the growth, physiological and biochemical parameters of lettuce (Lactuca sativa var. crispa) plants under drought stress conditions. Tests were carried out at different levels of vermicompost (0,2.5 and 5\%) and drought stress [no stress, moderate drought, and severe drought at 100, 50 and $25 \%$ of field capacity]. In comparison to control (vermicompost at $0 \%$ ), lettuce plants treated with vermicompost at 2.5 or $5 \%$ had higher shoot height, shoot fresh weight, relative water content, stomatal conductance, chlorophyll $a$, chlorophyll $b$, total chlorophyll and carotenoid contents under moderate and severe drought stress conditions. Malondialdehyde (MDA) content and superoxide dismutase (SOD) and catalase (CAT) activities increased while plants under drought stress conditions. Application of vermicompost caused higher SOD and CAT enzyme activities and lower MDA content under drought stress. Enhancement in antioxidant enzyme activities as a result of vermicompost destroyed reactive oxygen species. Therefore, application of vermicompost under moderate and severe drought stress decreased MDA content in lettuce plant cells. Data indicated a positive effect of the vermicompost on the growth of lettuce under drought stress conditions.
\end{abstract}

Keywords: antioxidant enzymes; drought; lettuce; pigment; vermicompost

Abbreviations: CAT: Catalase; chl $\mathrm{a}_{\mathrm{a}}$ Chlorophyll $a$; chl $_{\mathrm{b}}$ : Chlorophyll $b$; chl $\mathrm{l}_{\mathrm{t}}$ : Chlorophyll total; DS: Drought stress; EL: Electrolyte leakage; gs: Stomatal conductance; MDA: Malondialdehyde, RWC: Relative water content; SOD: Superoxide dismutase; VC: Vermicompost

\section{Introduction}

Environmental stresses (drought, salinity, high and low temperatures) adversely affect plants growth and productivity of crops. Abiotic factors affect plant evolution and water availability (Bowden et al., 2010). Morphological, physiological, biochemical and molecular changes occur in plants under abiotic stress conditions (Wang et al., 2001). An increase of solute concentration in environment under drought stress leads to an osmotic movement of water out of plant cells. High solute concentration inside plant cells causes low water potential and membranes disruption along with adverse effects on photosynthesis (Taheri-Asghari et al., 2009). Water deficit stress was reported to decrease plant height, leaf and root area, root length and biomass (Ramegowda et al., 2014). Increasing duration and severity of drought stress (DS) may decrease RWC of plants (Khan et al., 2017). RWC is a good indicator of leaf water status.
Drought stress increases RWC, resulting in some changes in cellular membrane and an increase in electrolyte leakage in the cells (Fu et al., 2004).

Stomatal activity, which is affected by DS, has an impact on photosynthesis and plant growth due to its effect on $\mathrm{CO}_{2}$ absorption. In response to a drought stress, ion and water-transport systems across membranes control turgor pressure changes in guard cells and stimulate stomatal closure (Osakabe et al., 2014). In addition, DS can change in photosynthetic pigment content. The $\mathrm{chl}_{\mathrm{a}}$ and $\mathrm{chl}_{\mathrm{b}}$ contents undergo to changes under DS (Farooq et al., 2009; Mibei et al., 2016). The carotenoids have shown to help plants to resist drought stress (Jaleel et al., 2009). The effects of DS on antioxidative enzymes responses have been studied in a number of plant species (Ansari et al., 2017). The relationship between plant antioxidative response to DS and susceptibility and tolerance to DS is still being investigated in many plant species. 
Generally, DS leads to a decrease in growth of susceptible plants. A high leaf water content and shallow root system of leafy vegetables, in particularly lettuce, make these crops vulnerable to DS. DS affected lettuce plant growth and productivity. VC was reported to increase beneficial microbial populations and thus improve soil fertility, which is important for the performance of the field and horticultural crops (Kazeminasab et al., 2016). VC was suggested to increase tolerance of plants to drought as an ecological alternative due its simulative effect on protein synthesis and enzyme synthesis and/or activity in various plant organs (Muscolo et al., 2007; García et al., 2012). For this reason, the use of $\mathrm{VC}$ in plants with high water content, like lettuce, can contribute to sustainable agriculture at the same time as it can be grown in drought conditions. In this study, the effects of VC on morphological, physiological and biochemical characteristics of lettuce under drought stress conditions were investigated. Thus, it was tried to determine the potential usage of $\mathrm{VC}$ in growth of lettuce under DS conditions.

\section{Materials and Methods}

\section{Plant materials and experimental treatments}

All plants were grown in Soil, Fertilizer and Water Resources Central Research Institute's greenhouse in Ankara (Turkey) from 24 March to the end of 10 July 2017. In the greenhouse, air temperature was set at $24 / 20$ ${ }^{\circ} \mathrm{C}$ (day/night) and relative humidity, 50-55\%. Commercial lettuce seeds were sown into a pot filled with vermiculite and perlite $[1: 1(\mathrm{v} / \mathrm{v})]$ until they germinated (24 March). At the 3-4 leaf stage, lettuce seedlings were transplanted into 7 $\mathrm{L}$ volume pots $(25 \mathrm{~cm}$ diameter by $22 \mathrm{~cm}$ deep) containing soil and VC at different ratios. One plant was grown per pot during this experiment. Lettuce plants were subjected to four ratios of VC and soil as follows: DS 0\%, 2.5\% VC, 5\% $\mathrm{VC}(\mathrm{w} / \mathrm{w})$ under different DS conditions. The chemical characteristics of the soil and VC are given in Table 1. DS conditions were as follows DS: control (non-stress; 100\% of field capacity-FC); moderate DS ( $50 \%$ of field capacity); severe DS ( $25 \%$ of field capacity). Pots were irrigated based on the FC (soil moisture content). After $48 \mathrm{~h}$ of irrigation to the saturation point, and drainage of gravity water, each pot was weighed and considered as FC 100\%. All FC levels (every day during the experiment) were separately weighed. The drought stress treatments were imposed 2 weeks after transplanting of seedlings to the pots (24 May). Plants were kept under these conditions for 46 days until harvest. After separating the shoot and root systems of each plant at harvest, they were used for morphological measurements.
The leaf samples were frozen in liquid nitrogen and stored at $-80^{\circ} \mathrm{C}$ until the physiological and biochemical analysis.

\section{Morphological measurements}

60 days after transplanting, shoot height, fresh weight ( $\mathrm{fr}$ $w t$ ), and dry weight (dry wt) of shoots were assessed in plant samples. The shoot samples were dried at $70{ }^{\circ} \mathrm{C}$ in an oven for $48 \mathrm{~h}$ to determine the dry wt.

\section{Physiological analysis}

RWC, gs, photosynthetic pigments and electrolyte leakage percent were measured 40 days after transplanting.

RWC is determined in fresh leaf samples. Leaf samples were weighed ( $\mathrm{fr} w \mathrm{w}$ ) and immediately floated on deionized distilled water for the next $8 \mathrm{~h}$, in dark. After removing the excess surface water of leaf sample, turgid weight was determined $(t w t)$. Leaf dry weight (dry wt) was recorded after drying leaf samples at $65^{\circ} \mathrm{C}$ for $48 \mathrm{~h}$. RWC was calculated using the following formula (Kaya and Higgs, 2003):

RWC $=100 \times[($ fr wt - dry wt $) /(t w t-$ dry wt $)]$

where: $\mathrm{fr} w \mathrm{t}=$ fresh weight; dry wt $=$ dry weight; $\mathrm{t} w \mathrm{wt}=$ turgid weight; $\mathrm{g}_{s}$ was determined by portable gas exchange measuring system leaf porometer (Model SC-1, Decagon). $\mathrm{g}_{s}$ was measured in the second youngest leaf of the plants in each treatment every fifteen days. Measurements were performed between 12:00 noon and 1:00 p.m.

To determine electrolyte leakage, $0.1 \mathrm{~g}$ of fresh leaf samples were weighted and placed into vials containing 10 $\mathrm{ml}$ distilled deionized water. After closing, vials were placed in a water bath and maintained at $32^{\circ} \mathrm{C}$. After 2 hours, the initial electrical conductivity of the medium (EC1) was measured. After autoclaving at $121{ }^{\circ} \mathrm{C}$ for $20 \mathrm{~min}$ and cooling down to $25^{\circ} \mathrm{C}$, the electrical conductivity of the leaf samples (EC2) was re-measured. The electrolyte leakage (EL) was calculated using the following formula (DionisioSese and Tobita, 1998):

$$
\mathrm{EL}=\mathrm{EC} 1 \mathrm{EC}^{-1} \times 100
$$

The method proposed by Lichtenthaler (1987), was used to measure chlorophyll (chl) and carotenoid contents. Fresh leaves $(0.1 \mathrm{~g})$ were mixed with $4 \mathrm{ml} 80 \%$ acetone and centrifuged at $4000 \mathrm{rpm}$ for $15 \mathrm{~min}$. The absorbance of the supernatant was measured at 647,664 , and $470 \mathrm{~nm}$ using a spectrophotometer (Perkin Elmer Lambda- EZ200). The $\mathrm{chl}$ and carotenoid pigments contents $\left(\mathrm{mg} \mathrm{g}^{-1}\right)$ were estimated using the formulas as follows:

$$
\mathrm{chl}_{\mathrm{a}}=12.21(\mathrm{~A} 664)-2.79(\mathrm{~A} 647)
$$

$\mathrm{chl}_{\mathrm{b}}=21.21(\mathrm{~A} 647)-5.1(\mathrm{~A} 664)$

$\operatorname{chl}_{\mathrm{t}}=\operatorname{chl}_{\mathrm{a}}+\operatorname{chl}_{\mathrm{b}}$

Carotenoid $=\left(1000 \mathrm{~A} 470-1.8 \mathrm{chl}_{\mathrm{a}}-85.02 \mathrm{chl}_{\mathrm{b}}\right) / 198$

\begin{tabular}{|c|c|c|}
\hline Properties & Soil & $\mathrm{VC}$ \\
\hline Soil texture & Sand clay loam & \\
\hline $\mathrm{pH}$ & 7.75 & 8.1 \\
\hline Electrical conductivity $(\mathrm{dS} / \mathrm{m})$ & 1.28 & 6.5 \\
\hline Organic matter $(\%)$ & 0.54 & 65.5 \\
\hline Nitrogen (\%) & 0.18 & 2.2 \\
\hline Phosphate (\%) & 3.60 & 1.7 \\
\hline Potash (\%) & 0.86 & 1.5 \\
\hline
\end{tabular}

Table 1. Soil and vermicompost (VC) properties 
354

\section{Biochemical analysis}

Enzyme extraction was performed by homogenizing $1 \mathrm{~g}$ of fresh leaf samples in $5 \mathrm{~mL}$ of $0.1 \mathrm{~mol} \mathrm{l}^{\mathrm{P}}$ potassium phosphate buffer $\left(\mathrm{pH}\right.$ 6.8) containing $0.1 \mathrm{mmol}^{-1}$ EDTA. After centrifugation at $12.000 \mathrm{rpm}$ for $20 \mathrm{~min}$ at $4{ }^{\circ} \mathrm{C}$, the supernatant was recovered and immediately used for the following enzyme assays. SOD activity was assayed according to the method by Beyer and Fridowich (1987), by monitoring the inhibition of photochemical reaction of nitro blue tetrazolium (NBT). The amount of enzyme required for the $50 \%$ inhibition of the reduction of NBT at $560 \mathrm{~nm}$ was defined as 1 unit of SOD activity. CAT activity was measured using the reaction mixture containing $2.6 \mathrm{ml}$ of $25 \mathrm{mM} \mathrm{Na}$-Phosphate buffer (pH 6.8), $400 \mu \mathrm{l}$ of $10 \mathrm{mM}$ $\mathrm{H}_{2} \mathrm{O}_{2}$, and $40 \mu \mathrm{l}$ of enzyme by the method of Cakmak and Horst (1991). The decomposition of $\mathrm{H}_{2} \mathrm{O}_{2}$ was followed by the decline of absorbance at $240 \mathrm{~nm}$.

Lipid peroxidation was determined by the MDA method in $200 \mathrm{mg}$ fresh leaves (Lutts et al., 1996). MDA content was determined by measuring absorbance of the supernatant at 532 and $600 \mathrm{~nm}$ [Extinction coefficient: 155 $\left.\mathrm{mM}^{-1} \mathrm{~cm}^{-1}\right]$ and expressed as $\mu \mathrm{mol} \mathrm{g} \mathrm{g}^{-1}$ fr wt.

\section{Experiment design and statistical analysis}

This research is conducted by applying completely randomized design, which consists of 2 factor and 4 replicates. Analysis of variance (ANOVA) was performed for statistical analysis of the data using MSTAT-C. Means were compared by Duncan's multiple range test $(\mathrm{p}<0.05)$.

\section{Results and Discussion}

\section{Morphological parameters}

The results showed a significant effect of VC, DS and their interaction on shoot height $(\mathrm{p}<0.05)$ (Table 2). As the DS level increased, the shoot height showed a decreasing trend. However, VC applications under DS conditions increased the shoot height (Fig. 1A). Shoot height of 5\% VC treated plants under moderate and severe drought stress was significantly higher than the respective controls. Studies have shown that the decrease in transpiration rate under water deficit stress significantly decreases plant height and dry matter content (Ramegowda et al., 2014). Bowden et al. (2010) found an increase in plant height as a result of the stimulation of auxin-like substances produced during VC consumption.

The results showed a significant effect of VC, DS and $\mathrm{DS} \times \mathrm{VC}$ interaction on shoot fresh weight $(\mathrm{Sfr} w \mathrm{w})(\mathrm{p}<$ 0.05) (Table 2). The fr wt of shoot decreased with the increasing raised DS level. The minimum fr wt was determined in the lowest irrigation regime ( $25 \%$ FC). This may be due to the decrease in the water consumption by the plant, thus leading to the decrease the absorption of nutrient elements of fr wt. Drought stress reduces plant growth through various physiological and biochemical processes. However, VC application increased the shoot $\mathrm{fr}$ wt (Fig. 1B). In agreement with our findings, BaghbaniArani et al. (2017) reported the improvement of the shoot fr wt wt of plants by VC application. Bacteria present in VC promote plant growth- due to its positive effects on the nitrogen fixation, solubilization of nutrients, and production of growth hormones (Azarmi et al., 2008). It has also been reported that vermicomposting contains biological compounds such as aqueous extract, auxine and cytokinin (García Martinez et al., 2002).

DS $\times$ VC interaction was not significant on shoot dry weight (Sdry wt) ( $p>0.05$ ) (Table 2). Compared to $100 \%$ FC treatment, the Sdry wt of plants decreased under DS condition. VC application increased the Sdry wt (Table 3) when the plants were irrigated with $100 \%$ FC treatment. A decrease in dry wt caused by DS is as a result of the joint effects of the osmotic stress, reduced $\mathrm{CO}_{2}$ assimilation and a change in nutrient concentration (Junjittakarn et al., 2013). It appears that the use of VC enhances absorption of water and nutrients due to its potential to encourage microbial activity (Amiri et al., 2017).

\section{Physiological parameters}

Table 2 presents the response of lettuce plant to DS and the effect of VC on RWC. A considerable difference in RWC was observed between the treatments of DS and VC $(\mathrm{p}<0.05)$. Water-stressed plants showed a significant decrease in RWC in comparison to other treatments. Many studies showed that water stressed plants had lower RWC than non-stressed ones (Vassileva et al., 2011; Cetinkaya et al., 2014; Gulen et al., 2018). The highest reduction was recorded in plants without VC under severe DS (25\% FC) (Fig. 1C). To determine the water status of crops under $100 \% \mathrm{FC}$ or DS conditions, one of the potential indicators is RWC having strong correlation with plant water relation. VC fertilizer improved growth traits such as RWC in lemon balm plants (Kazeminasab et al., 2016). In our study, the rise of the RWC has come about as a result of the VC. This may be due to the balance between water loss and ion uptake. Bio-fertilizers play a significant role in the process of photosynthesis and promotes plant growth by increasing RWC and nitrogen uptake (Han and Lee, 2015). Moreover, VC plays an important role in physical and

Table 2. ANOVA for morphological and some physiological parameters related to the traits of lettuce treated with vermicompost (VC) under drought stress (DS)

\begin{tabular}{|c|c|c|c|c|c|c|c|}
\hline $\begin{array}{l}\text { Source of } \\
\text { variance }\end{array}$ & $\mathrm{df}$ & SH & Sfr wt & Sdry wt & RWC & $g_{s}$ & $\mathrm{EL}$ \\
\hline DS & 2 & ** & ${ }^{* *}$ & ${ }^{* *}$ & ${ }^{* *}$ & ${ }^{* *}$ & ** \\
\hline VC & 2 & ** & ** & ** & ** & ** & ** \\
\hline $\mathrm{DS} \times \mathrm{xC}$ & 4 & $*$ & ** & $\mathrm{ns}$ & ** & ${ }^{* *}$ & $\mathrm{~ns}$ \\
\hline Error & 18 & 2.278 & 39.93 & 2.362 & 9.981 & 131.289 & 9.84 \\
\hline CV(\%) & & 6.62 & 5.22 & 8.86 & 4.49 & 7.54 & 13.09 \\
\hline
\end{tabular}

ns: Non significant, ${ }^{* *}$ and ${ }^{*}$, significant in $1 \%$ and $5 \%$ area. Shoot height $(\mathrm{SH})$, shoot fresh weight (Sfr wt), shoot dry weight (Sdry wt), relative water content (RWC), stomatal conductance $\left(\mathrm{g}_{\mathrm{s}}\right)$, electrolyte leakage $(\mathrm{EL})$. 

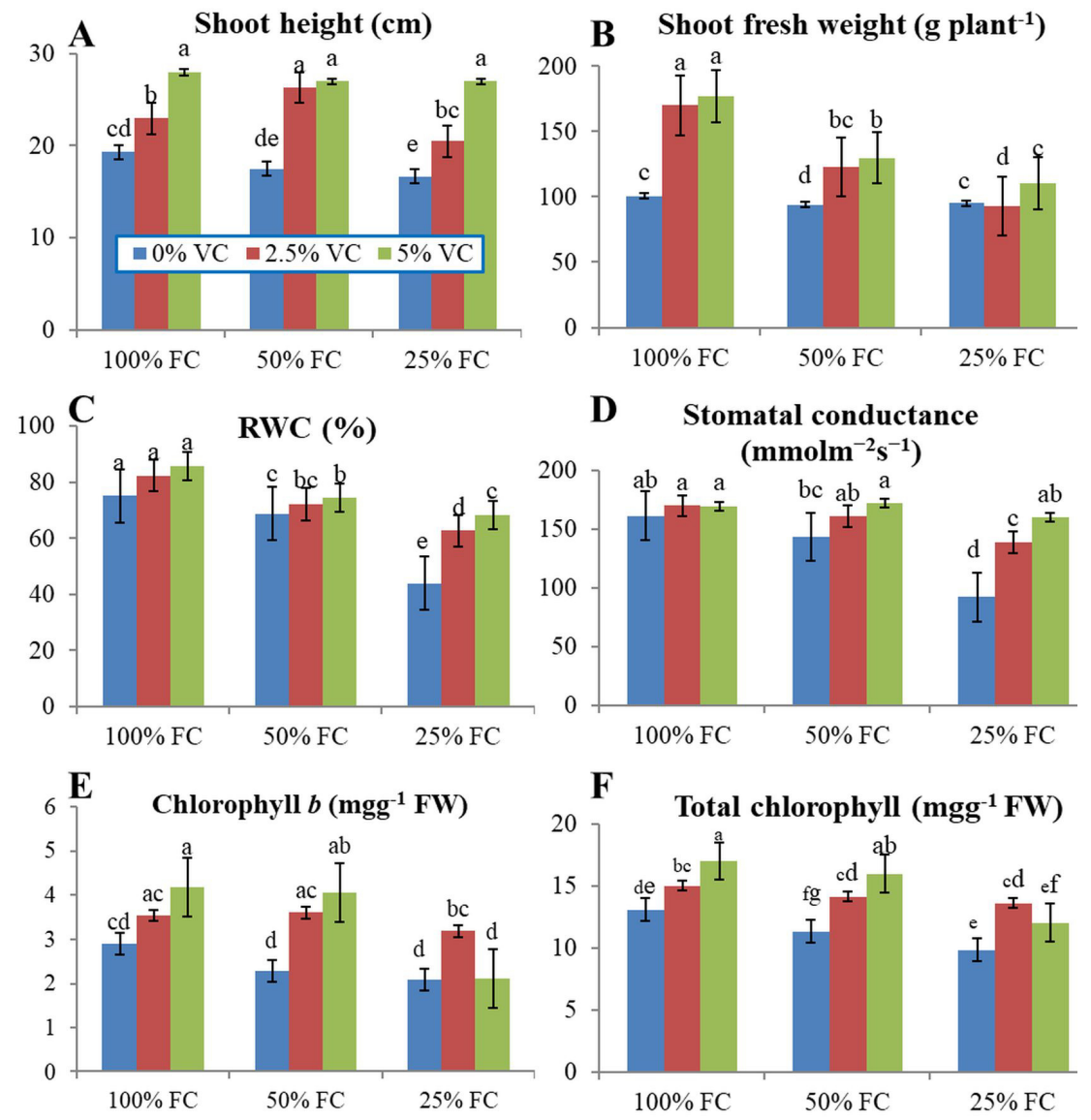

Fig. 1. Effect of drought stress (DS) and vermicompost (VC) interaction on shoot height (A), shoot fresh weight (B), relative water content (RWC) (C), stomatal conductance (D), chlorophyll $b$ (E) and total chlorophyll (F) contents. Means followed by the different letter are significantly different $(\mathrm{p}<0.05)$. DS conditions are as follows $100 \%$ field capacity (FC), $50 \%$ FC and $25 \%$ FC

hydraulic features of the soil texture, aeration, soil compaction and thus enhances more water and nutrients uptake by plants from their surrounding areas of root zone (Kashem et al., 2015).

DS $\times$ VC interaction was significant on $\mathrm{g}_{s}(\mathrm{p}<0.05) . \mathrm{g}_{s}$ of lettuce leaves decreased significantly under severe DS as, compared to $100 \%$ FC conditions (Table 2). gs plant treated with $5 \% \mathrm{VC}$ at $50 \% \mathrm{FC}$ and $25 \% \mathrm{FC}$ of irrigation regime exhibited higher values than other treatments (Fig. 1D). Important effects of DS on plants includes the decrease in leaf water potential and turgor loss, closure of stomata and decrease in internal $\mathrm{CO}_{2}$ concentration and $\mathrm{CO}_{2}$ assimilation (Rahbarian et al., 2011; Cetinkaya et al., 2014). VC limits stomata closure and increases $\mathrm{CO}_{2}$ supply necessary for photosynthesis due to fact that it has highly porous texture and high capacity for ventilation, proper drainage and water storage (Arancon et al., 2004). Also, as a result of VC application, increase in $\mathrm{g}_{s}$ can depend on increase in leaf relative humidity content.

The results obtained indicated no significant interaction effect between DS and VC treatment on electrolyte leakage $(\mathrm{p}>0.05)$ (Table 2). The reduced water availability under moderate and severe DS conditions caused significant increase in electrolyte leakage (Table 3). Application of VC caused a reduction in electrolyte leakage in plants subjected to DS.
$\mathrm{DS} \times \mathrm{VC}$ interaction was not significant on chl content $(\mathrm{p}>0.05)$ (Table 4). A reduction in water availability (from $100 \%$ FC to $25 \%$ FC treatment) led to significant decrease in leaf chl content (Table 3). The 5\% VC treated plants had the highest leaf $\mathrm{chl}_{\mathrm{a}}$ content, whereas the control (VC free) had the lowest leaf $\mathrm{chl}_{\mathrm{a}}$ content. Moreover, the interaction effects of DS and VC on the chl $\mathrm{b}_{\mathrm{b}}$ and chl contents were significant $(\mathrm{p}<0.05)$ (Table 4$)$. The chlb and $\mathrm{chl}_{\mathrm{t}}$ contents decreased under DS. Under moderate DS (50\% FC) plants treated with 2.5 and $5 \%$ VC showed a significant increase in chl content, compared to control treatment (Fig. 1E). However, 5\% VC-treated was not sufficient to increase $\mathrm{chl}_{\mathrm{b}}$ content under severe drought (25\% FC). The chl content demonstrated a downward trend in response to a decrease in DS; however, VC application prevented the decrease in chl (Fig. 1F). Thus, the highest $\mathrm{chl}_{\mathrm{t}}$ content was observed in the plant treated with $5 \%$ VC moderate stress ( $50 \%$ FC). The lowest chl content was observed in the control treatment under severe DS (25\% FC). Data indicated a decrease in leaf RWC with increasing DS. This may be due to the destruction of chloroplast and chlorophyll loss under DS. Reactive oxygen species (ROS) cause peroxidation and therefore degradation of chl pigments (Ramírez et al., 2014). Obtained results showed that leaf chl $\mathrm{b}_{\mathrm{b}}$ content decreased with increased DS, but $\mathrm{V}$ application increased the leaf chlb content. The delay 
356

in the destruction of photosynthetic pigments by VC application can be attributed to improved water efficiency. Previous reports have shown that VC application improved chl $\mathrm{l}_{\mathrm{t}}$ content in different plants such as Melissa officinalis $\mathrm{L}$. (Kazeminasab et al., 2016) under DS conditions.

DS $\times$ VC treatments interaction was significant on carotenoid content $(\mathrm{p}<0.05)($ Table 4$)$. In this study, carotenoid content decreased under water deficit conditions. Under moderato and severe DS (50\% and 25\% FC) were at the same level in carotenoid content. ROS activity can cause the loss of pigments such as chlorophyll and carotenoid. A decrease in contents of $\mathrm{chl}_{\mathrm{a}}, \mathrm{chl}_{\mathrm{b}}$ and carotenoids under DS in chickpea has also been reported (Baghbani-Arani et al., 2017). Obtained results showed that moderate and severe DS increases substantially the carotenoid content for all VC treaded over the control (Fig. $2 \mathrm{~A})$. VC application may have contributed to the further synthesis of carotenoids in stressed plants. The chl content is generally believed to be proportional to the amount of carotenoids that protect it (Amiri et al., 2017) thus; the increase in the carotenoid content for different VC treated can be attributed to the increase in chl synthesis.

\section{Biochemical parameters}

$\mathrm{DS}, \mathrm{VC}$ treatments and their interaction showed significant effects on MDA $(\mathrm{p}<0.05)$ (Table 4). An increase in DS intensity (50 and 25\% FC) led to increase leaf MDA content (Fig. 2B). Plants treated with VC under DS conditions exhibited lower values of lipid peroxidation than non-VC treated plants under DS condition. The 2.5 and $5 \% \mathrm{~V}$ applications have similar effect on lipid peroxidation under both DS conditions. The data indicate that VC treatment reduced effects of DS condition on the plants. MDA is a product of membrane lipid peroxidation and, considered a reliable marker of oxidative stress. It is routinely used to assess the degree of stress induced by oxidative damage in plants (Nayyar and Gupta, 2006). MDA levels increased in response to increasing stress level. The application of VC in rice under DS alleviated some of the deleterious stress-related effects on plant development (Patade et al., 2011; García et al., 2012). Findings obtained indicated a beneficial effect of $\mathrm{VC}$ on lettuce plant under DS plants. This may be as a result of a reduction in the ROS and membrane injury in response to DS.

Water shortages can cause oxidative damage. Antioxidative enzymes such as SOD and CAT alleviate the adverse effects of oxidative stress on plants. DS, VC treatments and their interaction significantly affected SOD and CAT contents $(\mathrm{p}<0.05)$ (Table 4). Fig. $2 \mathrm{C}$ and Fig. $2 \mathrm{D}$ show that increase in VC levels under DS led an increase in SOD and CAT contents of leaves, compared to control (100\% FC and without VC). The highest SOD enzyme activity was determined in plants treated with $5 \% \mathrm{VC}$ under DS (50\% and 25\% FC). CAT enzyme activity was highest in plants treated with 2.5 and $5 \% \mathrm{VC}$ under DS (25\% FC) SOD and CAT enzyme activities were induced when plants supplemented with VC under moderate and severe DS. Enhancement of SOD and CAT activities in VC treated plants may be induced by the drought resistance of lettuce plants. Application of VC can be used as a growth regulator which improves plant growth and enhanced stress tolerance. VC application may increase the uptake of ions such as K and Ca in the plant. Indeed, Andersen et al. (1992) reported that $\mathrm{Ca}$ acts as an activator for the enzyme and $\mathrm{K}$ inhibits plant damage by reducing transpiration. Higher activity of CAT and SOD decreased ROS level in cell, therefore; increased the stability of membranes and reduced lipid peroxidation. VC application increased SOD and CAT enzyme activities in the rice plants under drought stress (García et al., 2014; Wang et al., 2017).

Table 3. Comparison of mean effects of vermicompost (VC) and drought stress (DS)

\begin{tabular}{|c|c|c|c|}
\hline Traits treatments & Sdry wt, g plant $^{-1}$ & EL, \% & $\mathrm{chl}_{\mathrm{a}}, \mathrm{mg} \mathrm{g}^{-1}$ fr wt \\
\hline \multicolumn{4}{|l|}{ DS } \\
\hline $100 \% \mathrm{FC}$ & $19.05^{2}$ & $18.96^{\mathrm{b}}$ & $11.50^{a}$ \\
\hline $50 \% \mathrm{FC}$ & $17.632^{a}$ & $23.27^{b}$ & $10.51^{b}$ \\
\hline $25 \% \mathrm{FC}$ & $15.330^{b}$ & $29.70^{a}$ & $9.38^{c}$ \\
\hline \multicolumn{4}{|l|}{ VC } \\
\hline 0 & $10.68^{c}$ & $31.98^{a}$ & $9.00^{\mathrm{b}}$ \\
\hline $2.5 \%$ & $17.02^{b}$ & $22.17^{b}$ & $10.82^{a}$ \\
\hline $5 \%$ & $24.32^{a}$ & $17.94^{b}$ & $11.57^{\mathrm{a}}$ \\
\hline
\end{tabular}

Table 4. ANOVA for pigment contents, MDA, SOD and CAT enzymes related to the traits of lettuce treated with vermicompost (VC) under drought stress (DS)

\begin{tabular}{|c|c|c|c|c|c|c|c|c|}
\hline $\begin{array}{l}\text { Source of } \\
\text { variance }\end{array}$ & $\mathrm{df}$ & $\mathrm{chl}_{\mathrm{a}}$ & chlb & $\mathrm{chl}_{\mathrm{t}}$ & Carotenoid & $\mathrm{MDA}$ & SOD & CAT \\
\hline DS & 2 & ** & ** & ** & *** & ** & ** & $* *$ \\
\hline $\mathrm{VC}$ & 2 & ** & ** & ** & ** & ** & ** & ** \\
\hline $\mathrm{DS} \times \mathrm{xVC}$ & 4 & $\mathrm{~ns}$ & * & ${ }^{*}$ & $*$ & $* *$ & $* *$ & $* *$ \\
\hline Error & 18 & 1.00 & 0.26 & 0.85 & 0.09 & 0.53 & 124.58 & 194.23 \\
\hline $\mathrm{CV}(\%)$ & & 9.58 & 16.42 & 6.81 & 8.13 & 7.70 & 11.25 & 10.22 \\
\hline
\end{tabular}

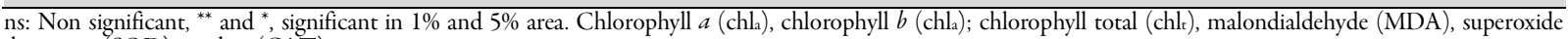
dismutase (SOD), catalase (CAT). 
A Carotenoid $\left(\mathbf{m g g}^{-1} \mathbf{F W}\right)$

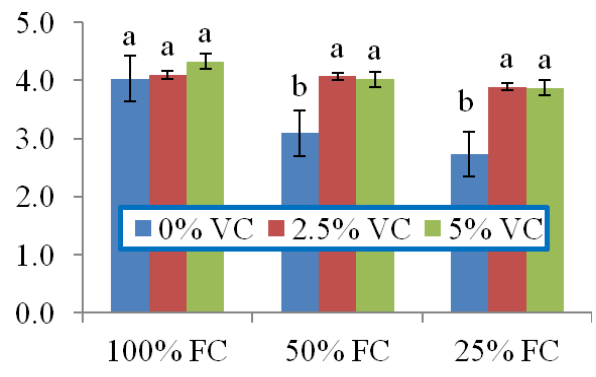

C

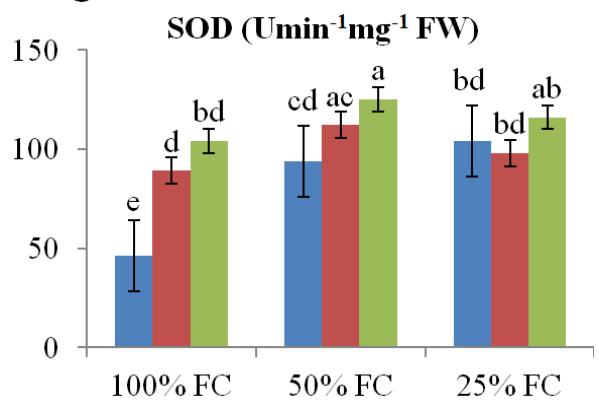

B $\operatorname{MDA}\left(\mu \operatorname{molg}^{-1} \mathbf{F W}\right)$

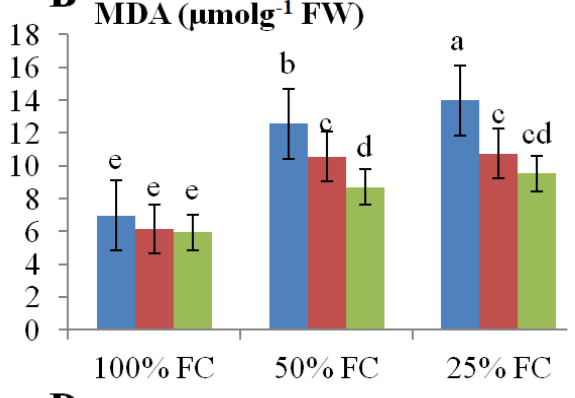

D

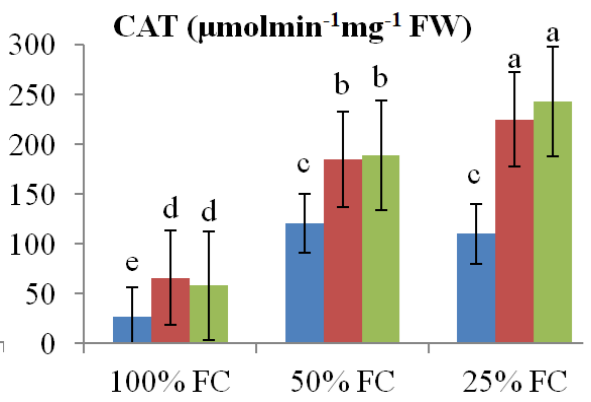

Fig. 2. Effect of drought stress (DS) and vermicompost (VC) interaction on carotenoid (A) and malondialdehyde (MDA) (B) contents, superoxide dismutase-SOD (C) and catalase CAT (D) enzym activities. Means followed by the different letter are significantly different $(\mathrm{p}<0.05)$. DS conditions are as follows $100 \%$ field capacity $(\mathrm{FC}), 50 \% \mathrm{FC}$ and $25 \% \mathrm{FC}$

\section{Conclusions}

Lettuce is sensitive to drought, which has adverse effects on morphological and physiological characteristics. VC at different ratios can increase lettuce growth in non-stress environment. In this study, we observed VC applications alleviated the adverse effects of DS on lettuce plant growth and related physiological process. VC improved plant growth under moderate and severe DS conditions. However, at 5\% VC severe drought (25\% FC), shoot height, Sfr wt, RWC, $g_{s}$ and SOD enzyme activity were more effective than $2.5 \% \mathrm{VC}$ and contributed to plant tolerance to drought. The beneficial effect of VC may be due to not only providing nutrient into the soil, but also containing the plant growth regulators or microorganisms which can change the soil structure and have positive effect on plant growth.

\section{Acknowledgements}

This research did not receive a specific grant from any funding organization in the public or commercial sectors. In addition, the author would like to thank the Center for Research on Soil Fertilizers and Water Resources for providing the working environment and facilities for this study.

\section{References}

Amiri H, Ismaili A, Hosseinzadeh SR (2017). Influence of vermicompost fertilizer and water deficit stress on morpho-physiological features of chickpea (Cicer arietinum L. cv. Karaj). Compost Science \& Utilization 25:152-165.
Andersen MN, Jensen CR, Lösch R (1992). The interaction effects of potassium and drought in field-grown barley. 1. Yield water-use efficiency and growth. Acta Agriculturae Scandinavica.Section B. Soil and Plant Science 42:3444.

Ansari WA, Atri N, Singh B, Pandey S (2017). Changes in antioxidant enzyme activities and gene expression in two muskmelon genotypes under progressive water stress. Biologia Plantarum 6:333-341.

Arancon NQ, Edwards CI, Bierman P, Welch C, Metzger TD (2004). Influences of vermicomposts on field strawberries: 1 . Effect on growth and yields. Bioresource Technology 93:145-153.

Azarmi R, Giglou MT, Taleshmikail RD (2008). Influence of vermicompost on soil chemical and physical properties in tomato (Lycopersicon esculentum) field. African Journal of Biotechnology 7:2397-2401.

Baghbani-Arani A, Modarres-Sanavya SA M, Mashhadi-Akbar-Boojar M, Mokhtassi-Bidgolia A (2017). Towards improving the agronomic performance, chlorophyll fluorescence parameters and pigments in fenugreek using zeolite and vermicompost under deficit water stress. Industrial Crops and Products 109:346-357.

Beyer WF, Fridovich I (1987). Assaying for superoxide disniutase activity: some large consequences of minor changes in conditions. Analytical Biochemistry 161:559-566.

Bowden C, Evanylo GK, Zhang X, Ervin EH, Seiler JR (2010). Soil carbon and physiological responses of corn and soybean to organic amendments. Compost Science \& Utilization 18:162-173.

Cakmak I, Horst W (1991). Effect of aluminum on lipid peroxidation, superoxide dismutase, catalase and peroxidase activities in root tip of soybean (Glycinemax). Plant Physiology 83:463-468. 
358

Cetinkaya H, Dinler Bs, Tasci E (2014). Investigation of comparative regulation on antioxidant enzyme system under copper treatment and drought stress in maize (Zea mays L.). Notulae Botanicae Horti AgrobotaniciCluj-Napoca 42(2):363-371.

Dionisio-Sese ML, Tobita S (1998). Antioxidant responses of rice seedlings to salinity stress. Plant Science 135:1-9.

Farooq M, Wahid A, Kobayashi N, Fujita D, Basra SMA (2009). Plant drought stress: effects, mechanisms and management. Agronomy for Sustainable Development 29:153-188.

Fu J, Fry J, Huang B (2004). Minimum water requirements of four turf grasses in the transition zone. Horticultural Science 39:1740-1744.

García AC, Santos LA, Izquierdo FG, Loss Sperandioa MV, Castroc RN, Berbara RLL (2012). Vermicompost humic acids as an ecological pathway to protect rice plant against oxidative stress. Ecological Engineering 47:203-208.

García AC, Santos LA, Izquierdo FG, Rumjanek VM, Castro RN, dos Santos FS, de Souza LGA (2014) . Potentialities of vermicompost humic acids to alleviate water stress in rice plants (Oryza sativa L). Journal of Geochemical Exploration 136:48-54.

García Martinez I, Cruz SF, Saavedra AL, Hernandez MS (2002). Extraction of auxin-like substances from compost. Crop Research 24:323-327.

Gulen H, Kesici M, Cetinkaya C, Ergin S (2018). Proline and antioxidant enzyme activities in some strawberry cultivars under drought and recovery. Notulae Botanicae Horti Agrobotanici Cluj-Napoca 46(2):570-578.

Han HS, Lee KD (2015). Plant growth promoting rhizobacteria effect on antioxidant status, photosynthesis, mineral uptake and growth of lettuce under soil salinity. Research Journal of Agriculture 1:210-215.

Jaleel CA, Manivannan P, Wahid A, Farooq M, Al-Juburi HJ, Somasundaram R, Panneerselvam R (2009). Drought stress in plants: A review on morphological characteristics and pigments composition. International Journal of Agriculture and Biology 11(1):100-105.

Junjittakarn J, Pimratch S, Jogloy S, Htoon W, Singkham N, Vorasoot N, Toomsan B, Holbrook CC, Patanothai A (2013). Nutrient uptake of peanut genotypes under different water regimes. International Journal of Plant Production 7:677-692.

Kashem MA, Sarker A, Hossain I, Islam MS (2015). Comparison of the effect of vermicompost and inorganic fertilizers on vegetative growth and fruit production of tomato (Solanum lycopersicum L.). Open Journal of Soil Science 5:53-58.

Kazeminasab A, Yarnia M, Lebaschy MH, Mirshekari B, Rejali F (2016). The effect of vermicompost and PGPR on physiological traits of lemon balm (Melissa officinalis L.). Journal of Medicinal Plants and By-products 2:135-144.

Kaya C, Higgs D (2003). Supplementary potassium nitrate improves salt tolerance in bell pepper plants. Journal of Plant Nutrition 26:13671382.
Khan A, AnwarY, Hasan MM, Iqbal AM, Alharby HF, Hakeem KR, Hasanuzzaman M (2017). Attenuation ofdrought stress in Brassica seedlings with exogenous application of $\mathrm{Ca}^{2+}$ and $\mathrm{H}_{2} \mathrm{O}_{2}$. Plants 6:2-13.

Lichtenthaler HK (1987). Chlorophyll fluorescence signatures of leaves during the autumnal chlorophyll breakdown. Journal of Plant Physiology 131:101-110.

Lutts S, Kinet J M, Bouharmont J (1996). NaCl-induced senescence in leaves of rice (Oryza sativa L.) cultivars differing in salinity resistance. Annals of Botany 78:389-398.

Mibei EK, Ambuko J, Giovannoni JJ, Onyango AN, Owina WO (2016). Carotenoid profiling of the leaves of selected African eggplant accessions subjected to drought stress. Food Science \& Nutrition 5:113-122.

Muscolo A, Sidari M, Attiná E, Francioso O, Tugnoli V, Nardi S (2007). Biological activity of humic substances is related to their chemical structure. Soil Science Society of America Journal 71:75-85.

Nayyar H, Gupta D (2006). Differential sensitivity of $C_{3}$ and $C_{4}$ plants to water deficit stress: association with oxidative stress and antioxidants Environmental and Experimental Botany 58:106-113.

Osakabe Y, Osakabe K, Shinozaki K, Tran LSP (2014). Response of plants to water stress. Frontiers in Plant Science 5:86.

Patade VY, Bhargava S, Suprasanna P (2011). Salt and drought tolerance of sugarcane under iso-osmotic salt and water stress: growth, osmolytes accumulation and antioxidant defense. Journal of Plant Interactions 6:275-282.

Rahbarian R, Khavari-Nejad R, Ganjeali A, Bagheri A, Najafi F (2011). Drought stress effects on photosynthesis, chlorophyll fluorescence and water relations in tolerant and susceptible chickpea (Cicer arietinum $\mathrm{L}$.) Genotypes. Acta Biologica Cracoviensia Series Botanica 53:47-56.

Ramegowda V, Basu S, Krishnan A, Pereira A (2014). Rice growth under drought kinase is required for drought tolerance and grain yield under normal and drought stress conditions. Plant Physiology 166:16341645.

Ramírez DA, Yactayo W, Gutiérreza R, Maresa V, De Mendiburuab F, Posadas A, Quiroz R (2014). Chlorophyll concentration in leaves is an indicator of potato tuber yield in water-shortage conditions. Scientia Horticulturae 168:202-209.

Taheri-Asghari M, Daneshian J, Aliabadi-Farahani H (2009). Effects of drought stress and planting density on quality and morphological of Chicory (Cichorium intybus L.). Asian Journal of Agricultural Sciences 1:12-14.

Vassileva V, Signarbieux C, Anders I, Feller U (2011). Genotypic variation in drought stress response and subsequent recovery of wheat (Triticum aestivum L.).Journal of Plant Research 124:147-154.

Wang WX, Vinocur B, Shoseyov O, Altman A (2001). Biotechnology of plant osmotic stress tolerance: physiological and molecular considerations. Acta Horticulturae 560:285-292.

Wang L, WangS, Chen W, LiH, DengX (2017). Physiological mechanisms contributing to increased water-use efficiency in winter wheat under organic fertilization. PloS One 12:1-21. 